\title{
COMPETENCIES ANALYSIS IN THE SUSTAINABLE DEVELOPMENT FIELD OF ELECTRICAL ENGINEERING BACCALAUREATE PROGRAM ALUMNI
}

\author{
Veronica Ivanova ${ }^{1}, K_{\text {seniya Mertins }}^{1, a}$ \\ ${ }^{1}$ National Research Tomsk Polytechnic University, 634050 Tomsk, Russia
}

\begin{abstract}
The term "sustainable development" is clarified. Criteria for the development of sustainable development in universities are selected. The analysis of the Electrical Engineering Baccalaureate Program for the development of competences for sustainable development is done. The conclusion about the need to develop smart university - sustainable development strategy of universities is made.
\end{abstract}

\section{Introduction}

The higher education system for engineering in Russia is undergoing a transition to a new educational paradigm - the professional training of specialists in a holistic manner. Addressing the need for sustainable use of natural resources, energy conservation, environmental protection, prevention of technological accidents, and risk management requires the active participation of engineers, with their particular knowledge and skills. Hence, the goal of education must be training specialists within a holistic life paradigm, so that they can be responsible citizens. Engineers trained in a systemic and holistic manner can become change agents in the practical implementation of the concept of sustainable development. The leading Russian technical universities are steadily moving in this direction.

According to UNESCO [1], education or the transmission, acquisition, creation and adaptation of information, knowledge, skills and values, is a key lever of sustainable development.

Scientists from different countries are sure that engineering students must be equipped with a wider knowledge base in terms of environmental, economic, and social attributes of engineered systems, work, and materials $[2,3,4]$.

\section{Methodology}

There are more than nine definitions of "sustainable development", in author's opinion it is necessary to make clarification. "Sustainable development" should reflect the multidisciplinary and interdisciplinary nature, including environmental, economic and social aspects. In conducting research, sustainable development is seen as a "process to ensure a deserving life activity and professional development, without compromising the ability of future generations to meet their needs for livelihood and development."

a Corresponding author: mertinskv@tpu.ru 


\section{Results and discussion}

The Federal Russian state educational standard of higher education provides a focus on results principle to transform the assessment of knowledge, abilities and skills in the evaluation of hard and soft skills.

Analysis of the «Electrical Engineering Baccalaureate Program (13.03.02) (in the field of intelligent energy) revealed the following learning outcomes [5], which form the model of sustainable development in the relevant industry:

1. The ability to understand and analyze social and economic problems and processes.

2. The ability to demonstrate knowledge of social, legal, cultural and environmental aspects of professional activity, knowledge of health, safety and labor electrical energy and electrical industries.

3. The ability to apply modern methods to develop energy-saving and environmentally clean technologies that ensure the safety of people and protecting them from the possible consequences of accidents, catastrophes and natural disasters; to apply the methods of rational use of raw materials, energy and other resources on electricity and electrical industries.

4. The willingness to enforce the industrial and labor discipline in the electricity and electrical industries; to develop new technological production processes; enforce the specified process parameters and product quality.

5. The ability to conduct preliminary technical and economic feasibility of design solutions; perform organizational and planning calculations for the establishment or reorganization of production sites, to plan the work of staff and funds remuneration; to determine and to ensure the effective modes of technological process.

The sustainable development model determines the range of relevant issues, developed and learned at different levels, which are used in teaching basics and principles of environmental management. In the educational process, there are various forms of informative activities energization of students in accordance with the discipline place in the module and the specification of generic competences in accordance with concentration [6].

In addition, the subjects of the curriculum (according to programs) tasks aimed at the development of competencies are included, namely:

- problem solving ("Integrated project");

- calculation of effects from human activities (hazard waste disposal), road transport (in the discipline "Ecology";

- the selection of new equipment ("Electrical engineering");

- assessment of technical condition of intelligent power systems (electrical science);

- rational using of raw materials, energy and other resources on the electricity and electrical industries ("Automation of electric power systems");

- analysis of financial and economic activity of the enterprises of electric power and electric engineering complex (calculation of break-even point-"Economics" );

- design of substations ("Fundamentals of design of energy systems");

- development of measures to reduce risk during project implementation development of the energy system ("Fundamentals of design of energy systems");

- design of the regional electric network 220/110 kV (Power systems and networks);

- and others.

It should be noted that smart grids project method allows not only to set a goal to complete the task, but also to develop the concept problem solution (including new energy sources), to ensure the result, to obtain the received data (including, for submission to the Client - employer, etc.).

To assess the quality of competences for sustainable development graduates need to enter the following criteria:

- availability of teachers with professional qualification in the field of sustainable development; 
- availability of orders from businesses (subjects research, R \& D) to address issues of sustainable development;

- presence educational program aimed at building competencies for sustainable development;

- presence of developments in the field of sustainable development, introduced in production;

- received grants on issues of sustainable development;

- growth rate of the quality of life of graduates;

- presence of publications both in Russian and foreign journals on the sustainable development of academic staff and graduates of the University;

- presence of the projects, protected in the form of team projects, to the coverage of sustainable development issues;

- academic staff and graduates motivation of solving problems related to sustainable development;

- system contests on sustainable development;

- existence of a resource efficiency university program;

- accreditation of Engineering Education for Sustainable Development;

- presence the industry, science and technology sustainable development in the fund assessment tools [7];

- policy on sustainable development (on the example of leading of enterprises and organizations);

- $\quad$ smart university (sustainable development strategy of universities).

\section{Conclusion}

As a result of the performed analysis it is necessary to draw conclusions about the recommended challenges in the education system to ensure competences for sustainable development:

1. Focus on design technology for the Educational Program (EP).

2. Increasing quantity of cases in the disciplines (fund assessment tools in collaboration with companies).

3. Introduction the curriculum of the foresight technology [8].

4. 4. Increasing quantity of discussed issues of sustainable development.

5. 5. Providing opportunities to develop problem-solving initiative projects (topics proposed by students).

6. 6. Consideration of sustainable development as a complex in the design and implementation strategies smart university and the opportunity to improve the EP, the quality of educational services and research.

7. 7. The focus on risk assessment in EP.

\section{References}

1. Education for the 21st Century. URL: http://en.unesco.org/themes/education-21st-century

2. J. Lonngren, M. Svanström, ASEE Annual Conference and Exposition, 26.255.1 - 26.255.13, (2015).

3. J. P. Davim, Sustainability in Higher Education. (Elsevier B.V., 2015)

4. Ingo Eilks, Euras. J. of Math., Sc. \& Tec. Ed., 11 (1), 149 (2015)

5. List of educational development programs in the TPU. URL: http://tpu.ru/f/1808/katalogobrazovatelnihprogrammtpu.pdf\#10 (2015)

6. What is education for suitable development. URL: https://www.plymouth.ac.uk/youruniversity/sustainability/sustainability-education/esd (2015) 
7. Engineering Education for Sustainability and Economic Growth in Developing Countries (the Sudanese Case). URL: http://ac.els-cdn.com/S1877042813042936/1-s2.0-S1877042813042936main.pdf? tid $=8062 \mathrm{f} 698-5 \mathrm{a} 1 \mathrm{f}-11 \mathrm{e} 5-$

8de500000aacb362\&acdnat $=1442152884 \mathrm{~d} 4 \mathrm{e} 7 \mathrm{fba0dcd} 3 \mathrm{db} 0 \mathrm{a} 536 \mathrm{f} 8 \mathrm{fd} 5538 \mathrm{ae} 10 \mathrm{e}$ (2015)

8. Creating value through foresight: First mover advantages and strategic agility. URL: http://www.sciencedirect.com/science/article/pii/S0040162514002558 (2015) 